\title{
DIALOG CHRZEŚCIJAŃSKO-ŻYDOWSKI W OCZACH WYZNAWCÓW JUDAIZMU
}

W wyniku ogłoszenia przez II Sobór Watykański deklaracji o stosunku do religii niechrześcijańskich (Nostra aetate) doszło do zainaugurowania dialogu między Kościołem i judaizmem ${ }^{1}$. Zgodnie z przekonaniem ojców soboru, wyrażonym na kartach wspomnianej deklaracji, Kościół poczuwa się do „duchowej więzi z plemieniem Abrahama" (DRN 4). Papież Jan Paweł II, który często nawiązuje dzisiaj do przewodnich idei 4. rozdziału tej deklaracji, nie zawahał się określić owej więzi mianem „uświęconej”, jako że bierze ona swój początek z tajemniczej woli Boga².

Mimo podjętych w ostatnim czasie wysiłków w kierunku wzajemnego zbliżenia, lud chrześcijański i żydowski pozostają nadal w stanie kontestacji, czy jak mówi św. Paweł — „współzawodnictwa” o rolę w zjednoczeniu ludzkiej rodziny $(\mathrm{Rz} 11,14)$. Promulgowanie przez Vaticanum II deklaracji Nostra aetate, potwierdzające trwanie narodu żydowskiego jako wymagającego partnera w stosunku do chrześcijaństwa, to impuls do uświadomienia sobie obopólnych zobowiązań. Dotychczasowe osiągnięcia i porażki dialogu, zainicjowanego przez DRN, uprawniają do umiarkowanej nadziei co do postępu w zbliżeniu chrześcijan i Żydów. Na obecnym etapie naiwnością byłoby osądzić, że każdy Żyd i każdy chrześcijanin akceptuje nową sytuację, jaką stwarza dialog i poprawnie odczytuje jego intencje. W wypadku katolików można przyjąć, że powodowani posłuszeństwem wiary uznają oni bodaj implicite za swoje stanowisko, jakie Kościół - Mater et Magistra - oficjalnie zajmuje w kwestii żydowskiej. Gdy idzie o wyznawców judaizmu, ich odpowiedź na ustalenia wypracowane przez środowiska zaangażowane $w$ dialog pozostaje $z$ natury rzeczy bar-

* W przypisach i tekście zastosowano następujące skróty:

ChJR - "Christian Jewish Relations" (zob. przypis 6).

DRN - Deklaracja o stosunku Kościoła do religii niechrześcijańskich (zob. przypis 1).

IJCIC - International Jewish Committee on Interreligious Consultations.

${ }_{1}^{1}$ Zob. Deklaracja o stosunku Kościoła do religii niechrześcijańskich, [w:] Sobór Watykański II. Konstytucje, dekrety, deklaracje, Poznań 1986, s. 333 - 336.

2 Zob. Jan Pawel II, Przemówienie do Komitetu Łązności, [w:] Insegnamenti di Giovanni Paolo II, vol. VIII/2, Città del Vaticano 1985, s. 1147; polskie tlumaczenie w: „Novum” 3 : 1986 s. 87. 
dziej spolaryzowana. Stan taki tłumaczy się wielością orientacji ideowych, składających się na rzeczywistość współczesnego judaizmu³ ${ }^{3}$. Spróbujmy więc prześledzić, jak Żydzi reagują na inicjatywy Kościoła w tym względzie.

\section{W POSZUKIWANIU PLASZCZYZNY DIALOGU}

Soborowa refleksja, uświadamiająca z nową mocą duchowe znaczenie Izraela dla życia chrześcijańskiej wspólnoty, wywodzi swą genezę z motywów teologicznych. Jest to potwierdzenie prawdy, iż Kościół nie ustaje w rewidowaniu i odnawianiu w swych postawach i wypowiedziach wszystkiego tego, co okazuje się za mało odpowiadać jego tożsamości, która opiera się na Słowie Bożym, na Starym i Nowym Testamencie — „tak, jak je odczytuje Kościól”4.

Gdyby badać motywy, jakimi kieruje się żydowski partner dialogu, zauważyć można, iż nie zawsze są one pochodzenia wyłącznie teologicznego. Jest to konsekwencją dzisiejszego stanu religii żydowskiej, gdzie prądy tradycyjne i konserwatywne krzyżują się z tendencjami liberalnymi i reformistycznymi. Judaizm to organizm składający się $\mathrm{z}$ wielu niezależnych członów, organizm mający zarazem charakter etniczny, religijny, kulturowy i polityczny. Wszystkie te elementy dochodzą do głosu w wypowiedziach wyznawców judaizmu zaangażowanych w dialog z Kościołem i rodzą niemałe trudności w ustaleniu płaszczyzny rozmów. Trudności owe można ująć w pojęciu asymetrii. Dotyczy ona problemu odpowiedniości struktur i instancji animujących dialog, pojawia się również przy zestawieniu priorytetów i zainteresowań. O ile dla strony katolickiej problematyką traktowaną priorytetowo jest problematyka teologiczna, to w świecie żydowskim wygląda to nieco inaczej. Centralne miejsce zdaje się tam zajmować problematyka historyczna, co w perspektywie dwudziestu wieków nie zawsze chlubnego dziedzictwa, obciążającego wzajemne współżycie, oraz w powiązaniu z żydowską tendencją do sakralizowania własnych dziejów rodzi skomplikowany splot zastrzeżeń.

Zadość czyniąc zasadzie „audiatur et altera pars”, sięgnijmy do miarodajnych źródeł, celem uchwycenia wielości żydowskich odpowiedzi na podejmowany przez Kościół wysiłek ponownego odczytania tajemnicy Izraela.

Okres posoborowy przyniósł obfitość publikacji z zakresu stosunków judeochrześcijańskich, przy czym strona żydowska wydaje się być w tej dziedzinie szczególnie aktywna. Wszystkie niemal żydowskie ośrodki naukowe i opiniotwórcze, rozsiane po całym świecie, poczuwają się do wyrażenia swego zdania na temat możliwości dialogu $\mathrm{z}$ chrześcijaństwem. Zróżnicowana jest też ranga tych wypowiedzi; od efemerycznych i odosobnionych, często ekstremalnych

-110 .

${ }^{3}$ Por. D. NOVAK, A Jewish Response to a New Christian Theology, „Judaism” 1 : 1982 s. 102

${ }^{4}$ Zob. wyżej przypis 2. 
głosów, po opinie wyważone i obiektywne. Pomocnym źródłem w poznaniu pluralistycznego stanowiska Żydów są nie tylko poszczególne pozycje uznanych autorów, lecz także naczelne periodyki, rejestrujące na bieżąco rozmaite głosy, jakimi świat żydowski reaguje na kroki Kościoła. Wymieńmy wśród nich choćby dwa tytuły. Pierwszy to „Judaizm”, pismo celujące w prezentacji opinii środowisk radykalnych, nierzadko sceptycznie ustosunkowanych do chrześcijaństwa, tym bardziej do propozycji ewentualnego zbliżenia ${ }^{5}$. Lektura zamieszczanych tam artykułów uświadamia, jak rozległy jest w judaizmie obszar postaw hermetycznych, a w najlepszym razie powściągliwych, gdy chodzi o ożywienie wzajemnych relacji. Ton sceptycyzmu, dominujący w artykułach wielu autorów kwartalnika „Judaism”, pozostaje w kontraście z otwartą i życzliwą postawą tych Żydów, którzy nie bez obaw podjęli ryzyko dialogu. Głosy tych ostatnich odnaleźć można na łamach innego kwartalnika żydowskiego, stanowiącego forum wymiany myśli na tematy związane wyłącznie z problematyką dialogu. Mowa o „Christian Jewish Relations”, piśmie powołanym do życia jako oficjalna trybuna, wyrażający stanowisko Żydów wobec zapoczątkowanej przez DRN nowej karty w odniesieniu Kościoła do „plemienia Abrahama”. Wydawany w Anglii, kwartalnik ten udostępnia swe łamy również chrześcijanom, których wypowiedzi bywają niekiedy przyczynkiem do interesujących polemik ${ }^{7}$.

W chwili obecnej dialog chrześcijańsko-żydowski legitymuje się już wypracowanymi przez zainteresowane strony strukturami i dokumentami. Powstanie ich było rezultatem ustalenia płaszczyzny dialogu. Proces ten szczególnie w przededniu soboru oraz $\mathrm{w}$ toku jego obrad uwzględniać musiał rozbieżne często oczekiwania, jakimi środowiska żydowskie reagowały na soborowe zaproszenie. Wyodrębnić można przynajmniej cztery różne odpowiedzi składające się na ówczesną postawę wyznawców judaizmu.

Część wspólnoty żydowskiej, obawiając się nowej sytuacji ekumenicznej, zachowała dyskretne milczenie. Powodów takiej poświągliwości i wyczekiwania można wyliczyć wiele. Rabin David Novak (Baruch College N.Y.) wskazuje na niektóre z nich. Po pierwsze, są Żydzi trwający w przekonaniu, że antysemityzm jest fenomenem o czysto chrześcijańskim rodowodzie, a shoah to naturalna kulminacja wielowiekowej nienawiści do Żydów i pogardy dla judaizmu. Po drugie, wielu Żydów nie wierzy w szczerość chrześcijańskich gestów przyjaźni, podejrzewając, że są one zakamuflowaną próbą prozelityzmu wobec niewiernych Izraelitów. Dalej — są i tacy, którzy sądzą, że otwarcie i dobra wola wobec wszystkich nie-Żydów, a szczególnie chrześcijan, były w historii

\footnotetext{
5 "Judaism”. A Quarterly Journal of American Jewish Congress, New York.

6 "Christian Jewish Relations". A Quarterly Published by the Institute of Jewish Affairs in Association with the World Jewish Congress, London.

${ }^{7} \mathrm{Z}$ okazji dwudziestolecia ogłoszenia DRN opublikowano na łamach ChJR wypowiedź kard. F. Macharskiego: A Polish Response to „Nostra aetate”, ChJR 4:1985 s. 4-5.
} 
konieczną, lecz poniżającą taktyką, dzisiaj już nieaktualną, skoro lud żydowski cieszy się suwerennością gwarantowaną przez własne państwo ${ }^{8}$. Przytoczone przez Novaka obiekcje jego współwyznawców pokazują, że rezerwa i uprzedzenia uwarunkowane historycznie stwarzają w dialogu chrześcijańskożydowskim największy dystans. Minione ćwierćwiecze, znaczone ożywieniem kontaktów, nie przyniosło widomego postępu w spojrzeniu na historię, sposoby jej przeżywania $\mathrm{i}$ interpretowania $\mathrm{w}$ wierze. Historia pozostaje nadal źródłem kontrowersji.

Następną grupę wątpliwości zgłaszają ci Żydzi, którzy nie kwestionując potrzeby polepszenia stosunków z chrześcijanami, pozostają sceptykami co do postępu w teologii, jaki miałby się zrodzić w rezultacie dialogu. Przedstawiciel takiego stanowiska rabin Richard Rubenstein sądzi, że dialog teologiczny jest nie do pomyślenia między ludźmi utrzymującymi, iż jedynie ich tradycja definitywnie wyraża drogę Bożą względem człowieka. Stąd naleganie Rubensteina na stworzenie naturalnej płaszczyzny w stosunkach chrześcijańsko-żydowskich, płaszczyzny wolnej od kontekstu religijnego. Autor ten stwierdza: „Prawdziwą tragedię stosunków żydowsko-chrześcijańskich stanowi to, że dla chrześcijan jest niemal rzeczą niemożliwą patrzeć na Żydów po prostu jak na ludzi, a nie jak na aktorów boskiego dramatu. Uczeni i teologowie chrześcijańscy nie wyświadczają nam żadnej przysługi, kiedy stwierdzają 'tajemnicę Izraela' i mówią o obowiązku kochania nas. Byłoby daleko lepiej, gdyby chrześcijanie i Żydzi traktowali się wzajemnie po prostu jako osoby" ". Dziwić mogą powyższe słowa w ustach autorytetu religijnego, szczególnie gdy zestawić je $\mathrm{z}$ katolicką perspektywą,sytuującą dialog z judaizmem nie na płaszczyźnie laickiego człowieczeństwa, lecz w wymiarze duchowego spotkania dwu ludów powołujących się na otrzymanie nieodwołalnych Bożych obietnic.

Poza sceptycyzmem, dyktowanym względami historycznymi i teologicznymi, obserwować można niekiedy postawę sceptycyzmu skrajnego, wyrażającą się w radykalnym odrzuceniu możliwości wszelkiej poważnej wymiany myśli chrześcijańsko-żydowskiej w jakiejkolwiek dziedzinie. Wyrazicielem takiego stanowiska jest Eliezer Berkovits (Columbia University N. Y.). Utrzymuje on; że chrześcijaństwo jest od czwartego wieku religią wojującą i że jego obecna chęć okazywania tolerancji wywodzi się nie z jakiejś wewnętrznej pokory, lecz jedynie z faktu, iż nie posiada ono już więcej potęgi, by panować. Dla Żydów, jako całości, uczciwy dialog z chrześcijanami jest emocjonalnie niemożliwy. Jest on również bezowocny. Zdaniem Berkovitsa „judaizm jest judaizmem, ponieważ odrzuca chrześcijaństwo i chrześcijaństwo jest chrześcijaństwem, ponieważ odrzuca judaizm; to, co nam przedstawiają jako tradycję judeochrześcijańską, istnieje jedynie w fantazji chrześcijan i sekularystów"10. Nie

${ }^{8}$ Zob. D. NovaK, jw., s. 116.

9 R. RUBENSTEIN, Torah and Gospel, „Judaism” 3 : 1965 s. 821.

${ }^{10}$ E. BERKOVITS, Judaism in the Post-Christian Era, „Judaism” 4 : 1966 s. 525. 
może więc być dla Berkovitsa żadnego dialogu: „Wszystko czego chcemy od chrześcijan, to tylko to, by wzięli swe ręce precz od nas i od naszych dzieci"11. Nieprzejednana postawa wobec chrześcijaństwa, w stylu przedstawionym powyżej, ilustruje stanowisko antagonistów domagających się utrzymania status $q u o, \mathrm{tj}$. separacji i nieufności w stosunkach z chrześcijanami.

Moralną przeciwwagę dla tendencji zmierzających do izolowania wspólnych elementów duchowego dziedzictwa stanowią Żydzi gotowi przezwyciężać bariery nieporozumień i budować na nowo zarówno życiowe stosunki, jak i doprowadzić do coraz żywszej wymiany myśli teologicznej. Poza sceptykami i antagonistami napotkać można w judaizmie szerokie kręgi zwolenników dialogu, dążących do ustalenia na każdym szczeblu kontaktów z chrześcijanami. W tym duchu wypowiada się wybitny teolog i myśliciel Abraham Joshua Heschel. Podkreśla on, że żadna religia nie jest „samotną wyspą”. Z tej racji występuje on z szerokim programem dialogu: „Nie mamy sobie wzajemnie pochlebiać, ani też się zwalczać. Celem jest wzajemna pomoc, dzielenie się intuicjami i nauką oraz - co jeszcze ważniejsze - wspólne szukanie źródeł na pustyni. Myślę o źródłach pobożności, siły miłowania i troski o człowieka ${ }^{12}$. Głęboko i bezkompromisowo oddani judaizmowi, ceniący sobie swą żydowskość Heschel i jemu podobni widzą w dialogu z chrystianizmem szansę rozwoju duchowych wartości obu tradycji religijnych, wspólny wysiłek nad ocaleniem promieniowania Biblii w umysłach ludzkich.

Zreferowane dotąd żydowskie głosy sceptyków, przeciwników i zwolenników dialogu pochodzą z okresu, gdy na soborze wypracowywano nową kartę stosunków Kościoła $\mathrm{z}$ judaizmem. Głosy te nie nawiązują jeszcze wprost do merytorycznych sformułowań deklaracji nostra aetate, ale krążą wokół zasadniczych pytań o sens dialogu z chrześcijaństwem, tak jak pojmują go współcześni wyznawcy judaizmu. Racje zniechęcające przeplatają się tutaj z argumentami pozytywnymi, te ostatnie okazały się na tyle rzeczowe, by posłużyć w okresie posoborowym za płaszczyznę dialogu.

\section{RECEPCJA GESTÓW KOSCIOŁA}

W łańcuchu inicjatyw, poprzez które Kościól potwierdza swą wolę odnowienia kontaktów $\mathrm{z}$ religią mojżeszową, naczelne miejsce zajmuje, jak już wspomniałem, deklaracja Nostra aetate, dokument wydobywający podstawowe elementy styczne rzeczywistości Kościoła i judaizmu, uświadamiający rozległość wspólnego dziedzictwa i wynikającej stąd więzi. Kolejne ogniwa w tym lańcuchu to odnośne struktury, dokumenty magisterium oraz dokonania

${ }^{11}$ Tamże, s. 82. s. 525 .

12 J. LicHTEN, Abraham Joshua Heschel - zycie, dzieło, postannictwo, „Znak” $1983 \mathrm{nr} 2-3$ 
papieży, w tym szczególnie zaangażowanie Jana Pawła II w kwestię żydowską. Nie pretendując do wyczerpania różnorodności żydowskich odpowiedzi na soborowe zaproszenie do dialogu, warto zapoznać się z niektórymi, najczęściej spotykanymi głosami, zrodzonymi w reakcji na kroki Kościoła.

Ogłoszenie ostatecznej wersji Nostra aetate wzbudziło w świecie żydowskim odczucia ambiwalentne. Doceniano przełom, jaki deklaracja ta zapowiadała w odniesieniu Kościoła do Żydów i judaizmu. „Z nadzieją i bez lęku mówił Pynchas Brener, naczelny rabin Wenezueli - podejmujemy wyciągniętą do nas przyjazną dłoń. Gest Kościoła zobowiązuje nas do głębszego wniknięcia we własne dziedzictwo, które tak skutecznie służy chrześcijaństwu jako inspiracja w jego misji pozyskiwania świata dla Jedynego Boga"13. Wedle słów innego teologa żydowskiego, „od Pawła do Pawła [tzn. od św. Pawła do Pawła VI] nikt tak otwarcie jak sobór nie podjął wyzwania judaizmu"14. Słowa te świadczą o nadziejach, jakie wiązano z soborowym oświadczeniem.

Jednocześnie jednak wyrażano rozczarowanie, iż dokument nie zwraca się bezpośrednio do wyznawców judaizmu, którzy oczekiwali, że Kościół wystąpi z aktem skruchy „za wielowiekową lekcję pogardy”. Radykalni odbiorcy twierdzili wprost, że deklaracja jest zawoalowanym wyrazem triumfalizmu Kościoła. Przekonaniu takiemu daje wyraz Jean Halperin, żydowski specjalista w dziedzinie stosunków międzyreligijnych: „Ogólnikowe sformułowania deklaracji świadczą o utrzymującej się wciąż w chrześcijaństwie pokusie patrzenia na nas [Żydów] jak na czcigodny przeżytek, świadków wzniosłej ale archaicznej tradycji religijnej"15. Ponadto żydowscy komentatorzy wskazywali na rażące braki w końcowej wersji owej deklaracji; chodziło im o pominięcie faktu odrodzenia państwa Izrael oraz przemilczenie holocaustu - dwóch dziejowych wydarzeń konstytuujących dzisiejszą świadomość żydowską.

Nie wszystkich zadowalał sposób, w jaki sobór podważył zarzut bogobójstwa. Pytano, dlaczego dokument nie nawiązuje wprost do tego pojęcia, poprzestając jedynie na rozgrzeszeniu Żydów z kolektywnej winy za śmierć Jezusa. Zwracano ponadto uwagę, że deklaracja nie wypowiada się na temat aktualnego znaczenia świadectwa judaizmu dla Kościoła i świata, nie precyzuje również, w jakim sensie należy interpretować trwałość Bożego Przymierza z Izraelem; czy posiada ono autonomiczną wartość, czy też podporządkowane jest Przymierzu, którego adresatem jest Kościól?

Lista zarzutów żydowskich kontestatorów tekstu soborowego jest wcale pokaźna. Nie sposób przytoczyć na tym miejscu wszystkich zastrzeżeń. Głosy krytyczne należy jednak uwzględnić na równi z wypowiedziami wyrażającymi zadowolenie i nadzieję wobec zapoczątkowanego przez Vaticanum II nowego poziomu współżycia chrześcijan i Żydów. Formułowane na gorąco sądy i opi-

${ }_{13}$ P. BRENER, The Future of Jewish Christian Relations, ChRJ $2: 1982$ s. 46.

${ }^{14}$ M. WAXMAN, Stepping Stones to Further Relations, ChjR : 1983 s. 59.

${ }^{15}$ Nostra Aetate Twenty Years on - A Symposium, ChJR : 1985 s. 19. 
nie na temat DRN, zdradzające nierzadko duże zaangażowanie emocjonalne, zostały z czasem poddane rewizji. Część $\mathrm{z}$ nich straciła swą aktualność $\mathrm{w}$ świetle kolejnych dokumentów Kościoła, przynoszących uściślenie i rozwinięcie kwestii sygnalizowanych w dokumencie wyjściowym. Okazało się, że sprowokowana przez deklarację żydowska krytyka pomogła w ustaleniu głównych tematów, jakich oczekiwano w dialogu z Kościołem. Dzięki swoim twórczym niedomówieniom, Nostra aetate dała asmupt do poszukiwania odpowiedzi na problemy, których znaczenie mogło ujść uwadze ojców soboru. Powodowani w pierwszym rzędzie troską o świadomość katolików, nie czuli się oni zobowiązani do sięgania po żydowskie kategorie teologiczne celem uwierzytelnienia swego stanowiska wobec judaizmu.

Precyzacje tego rodzaju przyniósł dokument wykonawczy deklaracji, jakim były opracowane przez Komisję do Spraw Stosunków Religijnych z Judaizmem i opublikowane w r. 1974 Orientacje i sugestie w sprawie wprowadzenia $w \dot{z}$ ycie deklaracji soborowej Nostra aetate ${ }^{16}$. O walorach tego dokumentu $\mathrm{z}$ uznaniem wypowiedział się Alfred Gottschalk (Hebrew Union College): „Potwierdzenie przez Stolicę Apostolską faktu istnienia pulsującej życiem tradycji animującej wspólnotę żydowską oraz zrozumienie znaczenia naszej samoświadomości jako warunku rozwoju wzajemnych stosunków, to dwa osiągnięcia Kościoła, świadczące o szczerości jego wysiłków w dialogu z Żydami. Nie jesteśmy łatwymi partnerami i dlatego tym większa nasza wdzięczność wobec tych katolików, którzy zabiegają o zbliżenie. Orientacje $i$ sugestie to jeszcze jeden dowód skuteczności działań Kościoła w dziedzinie dialogu"17.

Dokument wykonawczy DRN nie wzbudził tak wielu komentarzy, jak sama deklaracja. Jego wyważone sformułowania wychodziły naprzeciw postulatom stawianym w trakcie roboczych spotkań przedstawicieli Kościoła i judaizmu. Jeden z uczestników takich spotkań, rabin Norman Solomon, nawiązując do ukazania się Orientacji $i$ wskazówek stwierdził m. in.: „Pięćdziesiąt lat temu nikt z Żydów nie spodziewałby się jakiejkolwiek odmiany w stosunkach Kościół - judaizm. Musimy zdobyć się na cierpliwość, wystrzegać postawy: wszystko albo nic, według której rzeczywistym postępem w dialogu byłoby uznanie przez Watykan państwa Izrael, bądź po stronie żydowskiej spojrzenie na Jezusa oczami wiary" 18 .

Miarą oczekiwań, jakie zrodzily wśród Żydów deklaracja soborowa oraz jej późniejszy dokument wykonawczy, było kontrowersyjne przyjęcie ostatniego z szeregu istotnych dla zagadnienia opracowań, a mianowicie ogłoszonych w maju 1985 r. wskazówek katechetycznych: $\dot{Z} y d z i$ i judaizm $w$ gtoszeniu

16 Orientacje $i$ sugestie $w$ sprawie wprowadzenia $w$ życie deklaracji Nostra aetate $n r 4$, „Acta Apostolicae Sedis” 77 : 1975 s. $73-79$; thumaczenie polskie w: „Znak” : $1983 \mathrm{nr} 2-3 \mathrm{~s}$. $185-$ 187.

${ }^{17}$ Nostra Aetate Twenty Years..., s. 16.

${ }^{18}$ N. Solomon, Christian Jewish Dialogue: from Theology to the Classroom, „Journal of Ecumenical Studies" 3 : 1980 s. 437. 
Stowa Bożego i katechezie Kościoła katolickiego ${ }^{19}$. Żywiołowa dezaprobata, z jaką spotkały się niektóre z zawartych tam sformułowań, świadczy skądinąd o stopniu zaawansowania dialogu, wykraczającego już poza studium kurtuazyjnych posunięć. Warto zatrzymać się nieco dłużej przy polemice narosłej wokól dokumentu katechetycznego. Oddaje ona dość miarodajnie aktualny stan umysłów i przynosi dane o nastrojach panujących w środowiskach żydowskich odnośnie do szans dialogu z Kościołem.

Lista podstawowych zastrzeżeń zawarta została w oświadczeniu, jakie tuż po ogłoszeniu dokumentu wydane zostało przez International Jewish Committee on Interreligious Consultations (IJCIC), w czerwcu 1985 r. ${ }^{20}$ Autorzy oświadczenia podkreślają, iż katolicy nie otrzymali we Wskazówkach adekwatnej argumentacji w sprawie holocaustu oraz istnienia państwa Izrael. Oświadczenie głosi: „Rażącym przykładem nieadekwatności jest stwierdzenie, że istnienie Izraela nie powinno być odczytywane w perspektywie religijnej, lecz interpretowane zgodnie z obowiązującymi zasadami prawa międzynarodowego. A zatem nowożytny Izrael pozbawiony jest dla chrześcijań jakiegokolwiek znaczenia religijnego, co więcej — nawet religijne przywiązanie Żydów do swego państwa jest w dokumencie zbagatelizowane"21.

W odniesieniu do żydowskiej tradycji i historii IJCIC stwierdza, że chociaż intencją Wskazówek jest przeciwdziałać bolesnej ignorancji chrześcijan, dokument nie przynosi żadnego środka mogącego zmniejszyć jej rozmiary. „Ani żydowska tradycja, ani żydowska historia - czytamy w oświadczeniu - nie są analizowane lub bodaj wzmiankowane jako posiadające własną, autonomiczną wartość. Przedstawia się je jako etap przygotowawczy dla objawienia chrześcijańskiego. Nie zgadzamy się na takie instrumentalne traktowanie naszej historii”. Przedstawiciele IJCIC pytają dalej, dlaczego autorzy Wskazówek nie pokusili się o przytoczenie jakiegoś konkretnego przykładu historycznej ,animozji” chrześcijan do Żydów i judaizmu. „Objawiamy się, że w rezultacie rozpowszechnienia dokumentu katechetycznego może dojść do podważenia tych osiągnięć dialogu, jakie wypracowane zostały w minionym dwudziestoleciu"22.

Dziwić mogą rozmiary mylnej, a chwilami opacznej interpretacji, jakiej poddano intencje Wskazówek oraz niektóre z ich pozytywnych ustaleń. Dla katolików są one cenną pomocą do właściwego rozumienia problematyki judaistycznej. Żydów czytających dokument razi krótkowzroczność chrześcijan, którzy nie potrafili przewidzieć żydowskiej reakcji na jego kluczowe passusy, np. problem typologii czy nowożytnego państwa Izrael; nadto posłużyli się za-

${ }^{19}$ Żydzi i judaizm w gtoszeniu Stowa Bożego i katechezie Kościoła katolickiego, „L’Osservatore Romano" (wyd. polskie) $7: 1985$ s. $7-8$.

${ }^{20}$ Zob. Statement of the International Jewish Committee on Interreligious Consultations, ChJR : 1985 s. $74-76$.

${ }^{21}$ Tamże.

22 Tamże. 
wiłymi niuansami teologicznymi po to, by uniknąć jednoznacznego stawiania problemów.

Rzecznik takiego stanowiska, wiceprezydent Światowego Kongresu Żydowskiego, rabin Artur Hertzberg, twierdzi wprost, że wraz z ogłoszeniem dokumentu katechetycznego dialog chrześcijańsko-żydowski osiągnął swój teoretyczny kres. Przekroczenie go musiałoby przynieść rozczarowanie tak Żydom, jak i chrześcijanom, a to z powodu istnienia pewnych nierozstrzygalnych kwestii teologicznych i praktycznych. Powiedział on: „Ani Kościół jako całość, ani wspólnota żydowska nie podejmą rychło wezwania do abstrakcyjnego dialogu. Być może są wśród chrześcijan jednostki zdolne zrozumieć tajemnicę Izraela w kategoriach właściwych Żydom, podobnie jak w judaizmie indywidualni myśliciele mogą żywić sympatię dla tajemnicy Wcielenia. Nie widać jednak sposobu, w jaki te prywatne poglądy mogłyby wpłynąć na rzeczywiste odniesienie chrześcijan i Żydów zważywszy, że nasze najgłębsze oczekiwania teologiczne są nie do uzgodnienia"23. Sceptyczne prognozy Hertzberga równoważą głosy jego żydowskich polemistów, zamieszczone m. in. na łamach „Christian Jewish Relations". Podkreśla się tam, iż stosunki chrześcijańsko-żydowskie nie opierają się na chłodnej kalkulacji i samej tylko logice, a skoro inspiracja do zbliżenia pochodzi od Boga, to rozwój dialogu może przynieść niespodziewane efekty, tak jak okazało się to już w minionym okresie.

Obraz żydowskich reakcji względem magisterialnych wypowiedzi Kościoła pozwala dostrzec rosnące wymagania pod adresem katolickiego partnera dialogu. Jest to zrozumiałe w świetle postulatu postawionego w Orientacjach $i$ sugestiach: chrześcijanie winni znać judaizm taki, jaki on sam siebie określa. Znajomość tego rodzaju nie jest jednak równoznaczna $\mathrm{z}$ bezkrytycznym przyjęciem żydowskiego punktu widzenia w sprawach posiadających skądinąd własną kwalifikację teologiczną, wyrażoną w kategoriach chrześcijańskich.

Chwilowy impas, spowodowany krytycznym odbiorem w środowisku żydowskim dokumentu katechetycznego, nie anuluje dotychczasowych pozytywnych osiągnięć dialogu. Cytowane wypowiedzi nie powinny też prowadzić do wniosku, że nurt dezaprobaty wobec gestów Kościoła jest wśród wyznawców judaizmu nurtem dominującym. Jeżeli szerzej potraktowaliśmy głosy sceptyków, to z uwagi na to, iż nieczęsto istnieje możliwość pełniejszego się z nimi zapoznania. Ponadto specyficzny jest ton żydowskiej argumentacji. $\mathrm{Z}$ tych chociażby względów, pożyteczne wydawało się zaprezentowanie jej fragmentów w oryginalnym brzmieniu. Różnica stylów, jakimi posługują się strony dialogu, nie przesądza jeszcze o jego niepowodzeniu, co wyraził trafnie kard. Willebrands, mówiąc, iż skoro potrzeba było dwóch tysięcy lat, by powstała Nostra

${ }^{23}$ A. HertzBerg, The Common Bond-Reflections, ChJR : 1985 s. 21. 
aetate, to niepodobna oczekiwać, że w ciągu dwudziestu lat znikną wszystkie trudności ${ }^{24}$.

Dialog chrześcijańsko-żydowski to nie tylko spotkania okrągłego stołu, wymiana dokumentów i tworzenie kompetentnych struktur. Żywa tkanka tego dialogu domaga się, by był on „spotkaniem serc i umysłów”. Tak odczytuje sens zbliżenia Kościoła i judaizmu papież Jan Paweł II. Dla niego pełniejsze porozumienie z Żydami oznacza rozpoznanie „znaków czasu”. Kontynuuje on w tej mierze postawę swych poprzedników - Jana XXIII i Pawła VI. Świadectwo osobistego zaangażowania Jana Pawła II w kontakty z przedstawicielami judaizmu są być może nawet bardziej czytelnym znakiem dobrej woli Kościoła niż prestiżowe dokumenty, których zasięg nie jest tak powszechny, jak papieskiego nauczania.

Wspólnoty żydowskie od początku pontyfikatu związały z osobą Jana Pawła II żywsze nadzieje, gdy idzie o potwierdzenie roli ich religijnej i etnicznej obecności we wspólnocie narodów. Popierając wysiłki najwyższych instancji, odpowiedzialnych za rozwój wzajemnych stosunków, Jan Paweł II przenosi je jednocześnie na grunt osobistych, międzyludzkich kontaktów. Znajduje to wyraz w częstych audiencjach i spotkaniach papieża $\mathrm{z}$ wyznawcami judaizmu. W czasie swoich apostolskich podróży Jan Paweł II wykorzystuje spotkania z Żydami do podzielenia się refleksją nad stanem stosunków chrześcijańskożydowskich, nad drogą już przebytą oraz nad tym, co wciąż jeszcze pozostaje nie zapisaną kartą dialogu. Wizyta Biskupa Rzymu w głównej synagodze wiecznego miasta, zdecydowane stanowisko wobec ataków antysemickich, to kolejne kroki ku tworzeniu klimatu pojednania, kroki przyjmowane $\mathrm{z}$ uznaniem przez wspólnotę żydowską. Tu i ówdzie odzywają się również głosy malkontentów krytykujących papieża, przykładowo za jego troskę o losy Palestyńczyków, bądź własne stanowisko w „sprawie Waldheima”. Problemy te nie leżą jednak w zasadniczym nurcie dialogu chrześcijańsko-żydowskiego i nic nie wskazuje, by mogły zakwestionować wiarygodność, jaką Jan Paweł II cieszy się w środowiskach żydowskich ${ }^{25}$.

W świetle tego zatem, co wyżej powiedziano, można twierdzić, że po stronie żydowskiej wytworzył się klimat otwarcia, a przynajmniej świadomości, iż racja żydowska znajdzie w Kościele posłuchanie. Świadczy o tym uwaga, z jaką świat żydowski śledzi poczynania Kościoła, oraz żywa, nieraz kontrowersyjna reakcja na wszelkie nowe pociągnięcia chrześcijan w dziedzinie dialogu.

\section{OCZEKIWANIA I DEZYDERATY}

Uwagi i zarzuty, formułowane przez Żydów w odpowiedzi na dokumenty

${ }^{24}$ Zob. J. Willebrands, Vatican II and the Jews: Twenty Years Later, ChJR : 1985 s. $51-62$.

${ }^{25}$ Zob. A. HertzBerg, jw., s. 23. 
Kościoła, kryją w sobie pakiet życzeń i oczekiwań, skierowanych przez wyznawców judaizmu do chrześcijan, ożywionych duchem dialogu. Jest więc rzeczą pożądaną zbadać, jak chrześcijaństwo i jego fundamentalne prawdy rysują się w oczach ortodoksyjnych Żydów. Ich optyka wyznacza w pewnym sensie ramy dialogu z Kościołem, który w swoich inicjatywach stara się uwzględniać wrażliwość żydowską. Zapoznając się z poglądami badaczy żydowskich, trzeba być świadomym istniejących różnic, aby nie zgorszyć się np. negowaniem bóstwa Chrystusa, sformulowaniami o „bluźnierstwie Wcielenia”, jak również zbyt pretensjonalnym tonem niektórych roszczeń pod adresem Kościoła ${ }^{26}$. W radykalnym ujęciu można wyróżnić trzy tematy, które na poziomie teologicznym najbardziej ekscytują autorów żydowskich. Są nimi: tożsamość Jezusa, Kościół i Synagoga oraz status teologiczny państwa Izrael.

Osoba Jezusa jest zdaniem żydowskich uczestników dialogu tym problemem, który natarczywie powraca jako centralny punkt odniesienia w poczynaniach strony chrześcijańskiej. „We wszystkich katolickich dokumentach mówi A. Hertzberg - można wyczytać między wierszami utajone głęboko pragnienie, by Żydzi zgodzili się, iż Jezus jest integralną częścią ich religijnej historii, a w związku z tym, teologia żydowska powinna uwzględniać jego postać w stopniu nie mniejszym niż teologia katolicka czyni to w odniesieniu do Mojżesza i Patriarchów. Ilekroć powtarzamy przy okazji wspólnych dyskusji, że Jezus jest dla nas tak samo ważny, jak Mahomet dla chrześcijaństwa katolicy przyjmują to z niedowierzaniem"27.

W żydowskiej refleksji doktrynalnej panuje przekonanie, że wiara w Jezusa i osobista $\mathrm{z}$ Nim więź mogą w pewnych wypadkach umożliwić poganom osiągnięcie zbawienia i przystęp do Ojca, to znaczy do Boga Izraela. Jeśli można się zgodzić, że droga ta adekwatna jest dla „goim”, to opór Żydów budzi fakt, że Kościół - w ich mniemaniu usiłuje narzucić tę drogę narodowi, z którego wyszedł Jezus. W tym miejscu myśl żydowska stoi w opozycji do wiary chrześcijańskiej. Dla chrześcijan, osoba Jezusa, Jego proroctwo i paschalne dzieło są kulminacją dziejów zbawienia. Żydzi umieszczają je w łonie Przymierza zawartego z Izraelem, stanowiącego, według nich, centrum Przymierza z całą ludzkością. Dzisiejszym wyznawcom judaizmu nie przeszkadza w pierwszym rzędzie to, że chrześcijanie obwołali Jezusa Mesjaszem. Za bluźnierstwo uważają oni Jego boskie roszczenia oraz ideę Wcielenia Boga w syna kobiety. Wyczulony zmysł Bożej transcendencji każe im odrzucić taki „naturalizm” i takie uczłowieczenie Bożej mocy.

Rozbieżność perspektyw w spojrzeniu na Jezusa jest niezbywalnym tłem, na którym rozgrywają się koleje dialogu judeochrześcijańskiego. Ta fundamentalna niezgodność nie oznacza, że jego uczestnicy skazani są na poruszanie 58.

${ }^{26}$ Zob. A. ABECAssis, Chrześcijaństwo widziane przez judaizm, „W Drodze” : 1986 s. 45 ${ }^{27}$ A. Hertzberg, jw., s. 22. 
kwestii jedynie marginalnych, zważywszy że najmniejszy nawet problem, stawiany na wokandzie dialogu, posiada własne znaczenie teologiczne i stanowi część owego „nexus mysterioris”, którego depozytariuszami słusznie mogą mienić się tak chrześcijanie, jak i Żydzi.

Kościół, rozumiejąc opory, na jakie w świadomości żydowskiej napotyka idea Boskiej Inkarnacji, mimo iż pragnie, by nowina o Jezusie Chrystusie stała się radością wszystkich, nie narzuca jej Żydom arbitralnie, w trosce o pielęgnowanie tych nici porozumienia, które wypracowano już w toku dialogu. Postawa taka nie pozostaje bez wpływu na miejsce, jakie we współczesnej myśli żydowskiej zajmuje Jezus z Nazaretu. Nie należą tam już dzisiaj do rzadkości samorzutnie podejmowane próby odnalezienia w posłaniu Jezusa elementów istotnych dla nauki i duchowości judaizmu ${ }^{28}$.

Kolejnym punktem dialogu, który badacze żydowscy obwarowują szeregiem zastrzeżeń i dezyderatów, jest problem współistnienia Synagogi i Kościoła. Według Tory i Ewangelii - mówią Żydzi - tylko Izrael jest narodem wybranym i tylko naród żydowski jest nazwany Izraelem. Teologowie chrześcijańscy, którzy ukuli pojęcie „nowego Izraela”, ignorują historię biblijną, jak też ducha i literę ewangelicznego orędzia. Usiłują w ten sposób wykazać, że Kościół urzeczywistnia erę mesjańską, skoro nadzieja na powrót Jezusa musiała z czasem osłabnąć. We wzywaniu zatem Izraela do ustąpienia miejsca Kościołowi, jako społeczności otwartej i uniwersalnej, wyższej niż zamknięta spoleczność żydowska, ujawnia się pozbawione pierwiastka religijnego poczucie wyższości chrześcijan ${ }^{29}$. „Nie życzymy sobie — głosi oświadczenie IJCIC przypisywania Izraelowi perspektyw i kategorii typologicznych odnoszących się do Kościoła"30. Kościól, w oczekiwaniu Żydów, powinien przyjąć, że jest tylko jeden Izrael — naród żydowski. Wymaga to pokory, ale przysłużyłaby się ona chrześcijaństwu w realizacji Bożego planu, dokonywanego z pomocą narodu żydowskiego. Izrael, naród odpowiedzialny przed Bogiem za całą ludzkość, nie musi iść przez Jezusa i jego Kościól, aby dojść do Ojca. On sam jest synem pierworodnym Boga, Boga Jezusa, i chlubi się drogą, która doń wiedzie, a jest nią Tora i wierność jej prawu ${ }^{31}$.

Poglądy powyższe, będące skrótem żydowskiej perspektywy na koegzystencję Synagogi i Kościoła, mogą razić swoim ekskluzywizmem. Uwzględniają one wprawdzie misję Kościoła jako współbrzmiącą z posłannictwem Izraela, lecz z punktu widzenia eklezjologii katolickiej wiele z tych sformułowań jest nie do przyjęcia, chyba że za cenę rezygnacji z własnej tożsamości. Poza tym, arbitralne postulaty Żydów niosą dla Kościoła wezwanie do nieustannego zgłę-

28 Por. J. NiEMCZYK, Jezus z Nazaretu w świetle wspótczesnej myśli żydowskiej, „Roczniki Teologiczne Chrześcijańskiej Akademii Teologicznej w Warszawie" 1983 s. $61-110$.

${ }^{29}$ Por. H. BAMBERGER, Some Difficulties in Dialogue, „Judaism” : 1983 s. 715 - 741.

${ }^{30}$ Statement of the IJCIC..., s. 75.

${ }^{31}$ Por. A. AbeCassis, jw., s. 57. 
biania rzeczywistego sensu Objawienia jaśniejącego w Osobie Jezusa, który jest zarazem jego pośrednikiem i pełnią (por. KO 2).

Trzeci rozległy obszar żydowskich oczekiwań w dialogu z Kościołem to rzeczywistość państwa Izrael. Należy jednak uściślić; nie chodzi o państwo jako takie, lecz o terytorialny, geograficzny wymiar judaizmu. Stanowi on część żydowskiej tradycji religijnej. Potwierdzeniem tego faktu jest sprzeciw wywołany sugestią Wskazówek katechetycznych, by kwestię państwa Izrael rozpatrywać w odwołaniu do ogólnych zasad prawa międzynarodowego, nie zaś w perspektywie czysto religijnej. To sformułowanie, wyważone i nie kwestionujące religijnej więzi, jaką wspólnota żydowska żywi do ziemi przodków, uznane zostało przez niektórych Żydów, wyznających skrypturystyczny fundamentalizm, za kamień obrazy. Współcześni spadkobiercy ziemi Izraela oczekują od Kościoła głębszego wniknięcia w rzeczywistą naturę żydowskiego mesjanizmu. Ma on podwójny wymiar: duchowy i geograficzny. Według Żydów powrót ich narodu do Ziemi Obiecanej wpisany jest na trwałe w Boże plany. Oczekują oni, iż Kościól swoim moralnym poparciem pomoże narodowi żydowskiemu właśnie na tej ziemi budować społeczeństwo, jakiego Bóg pragnie od czasów Abrahama $^{32}$.

Poza przedstawionymi powyżej trzema wiodącymi wyzwaniami, składającymi się na merytoryczną osnowę dialogu judeochrześcijańskiego, istnieje wiele innych zobowiązań, których podjęcia oczekują od siebie nawzajem przedstawiciele obu wspólnot religijnych. Jedno z takich zadań, to troska o upowszechnianie dotychczasowych osiągnięć dialogu wśród szerokich kręgów wyznawców. Dopóki owoce wspólnych wysiłków będą przedmiotem zainteresowania dla wąskich jedynie elit, dopóty $\mathrm{z}$ trudem wypracowywane ustalenia mogą się okazać martwą literą.

Dla dopełnienia obrazu żydowskich odpowiedzi na soborową inicjatywę dialogu, wspomnieć trzeba jeszcze o świadectwie tych Żydów, którzy zgłębiając judaizm, spotkali Jezusa i rozpoznawszy w Nim Mesjasza, przyjęli chrzest we wspólnocie Kościoła katolickiego. Z uwagi na swą odmienną jakość, głosy konwertytów żydowskich na temat dialogu nie mieszczą się w tym samym planie, co opinie zdeklarowanych wyznawców judaizmu.

Pierwsza tęsknota, jaką w chrześcijanach kręgu żydowskiego wzbudza rozwijający się dialog, związana jest $\mathrm{z}$ dowartościowaniem ich obecności w łonie Kościoła $^{33}$. Dobrze się przeto stało, iż we Wskazówkach katechetycznych znalazło się przypomnienie faktu istnienia „Ecclesia ex circumcisone”, z którego początek bierze „Ecclesia ex gentibus” (por. Wskazówki III 4).

Innym znamiennym rysem duchowej sylwetki współczesnych konwertytów żydowskich jest przywiązanie do ziemi Izraela. Wierność ziemi biblijnej łączą

32 Por. D. SInger, Catholic Attitudes Toward the Jewish State, „Journal of Ecumenical Studies" : 1985 s. $650-672$.

${ }^{33}$ Por. K. Strzelecka, Shalom, Warszawa 1987, s. 186. 
oni jednak z nadziejami specyficznie chrześcijańskimi. Ich treścią jest szansa rozpoznania Jezusa przez ogół Żydów zgromadzonych na ziemi praojców, rozpoznania dokonanego niejako ad intra ${ }^{34}$. Nadzieja takiego odkrycia, również i dla chrześcijan, powinna stanowić impuls do otwarcía się na naród żydowski, a szczególnie na tę jego cząstkę, którą tworzą żydowscy wyznawcy Chrystusa.

W toku posoborowego ożywienia stosunków między Kościołem i judaizmem doszło (nie bez zrozumiałych w tym wypadku trudności) do ustalenia „porządku dziennego” w dialogu judeo-chrześcijańskim. Obejmuje on zagadnienia teologiczne, uwzględnia wszakże i inne istotne wymiary rzeczywistości Kościoła i Izraela. W optyce chrześcijańskiej największe znaczenie posiadają te spośród nich, które niosą implikacje doktrynalne. Żydzi nie zawsze podzielają taką hierarchię problemów, przesuwając akcent na tematy historyczne, społeczne, a także polityczne. Tak wyłoniła się potrzeba respektowania asymetrii, występującej na poziomie priorytetów, jakimi powodują się partnerzy dialogu. Zaznacza się ona również na poziomie szczegółowych pojęć, takich jak Przymierze, Mesjasz, Lud Boży, ziemia Izraela itp.

Staraliśmy się zaprezentować różnorodne stanowiska, z jakimi przedstawiciele judaizmu występują wobec zaproszenia do dialogu. Nie zawsze jest to aprobata, czasem nawet irytacja, jednakże margines kontestacji nie przesłania pozytywnego oddźwięku, jaki w świecie żydowskim wywołują inicjatywy Kościoła szukającego porozumienia ze „starszym bratem” — Izraelem.

Chrześcijanie poprzez dialog z Żydami uczą się doceniać bogactwo i żywotność żydowskiej wiary w Przymierzu z Bogiem. Odnowiona na soborze świadomość eklezjologiczna sprawia, iż Kościół dąży do tego, by wzbogacać się wartościami, jakie noszą w sobie jego korzenie.

Żydzi ze swej strony, mimo nieuniknionej dozy sceptycyzmu, nie uchylają się od dialogu $\mathrm{z}$ religią, która $\mathrm{z}$ wielu względów jest im najbliższa. Oczekują, iż chrześcijanie, którzy wierzą, że Mesjasz już przyszedł, będą tym bardziej zabiegać o wcielanie ideału człowieczeństwa i udoskonalenie świata, tak żeby był on godny tego Mesjasza.

Powstaje pytanie, czy naród żydowski jest zawsze zdolny do tego, by ukazywać przymioty i posłannictwo ludu wybranego i czy Kościół oparty na Piotrze, jaki tworzą chrześcijanie, jest zawsze i pod każdym względem wobec świata taki, jakiego pragnąl Rabbi, Prorok, Syn Człowieczy i Syn Boży - Jezus Chrystus. Częścią odpowiedzi na to pytanie, nie mniej ważną niż spekulacje teologi-

34 Por. tamże, s. 178. 
czne, jest życiem potwierdzona wiara, jaką zgodnie ze swymi przekonaniami wyznają chrześcijanie i Żydzi. Żydowskie świadectwa składane wobec nowego odniesienia Kościoła do judaizmu pozwalają myśleć, iż „czas zszywania” tego, co we współżyciu chrześcijan i Żydów długie wieki pozostawało w nieładzie, ostatecznie nadszedł wraz z soborem i deklaracją Nostra aetate. Jest to proces otwarty, choć z przytoczonych symptomów widać, iż będzie długi i niełatwy.

\author{
DIALOG ZWISCHEN CHRISTEN UND JUDEN \\ IN DER AUFFASSUNG DER JUDAISMUSANHÄNGER
}

\title{
Zusammenfassung
}

Der jüdisch-christliche Dialog nahm seinem Anfang mit der Erklärung des Konzils Nostra aetate. Den Kernpunkt dieses Vorhabens bildet die Wahrheit über das Bestehen eines Bündnisses zwichen der Kirche und dem Stamm des Abraham. Von der theologischen Feststellung der Seelenverwerwandschaft zwischen Christen und Juden aus ergaben sich in der Zeit nach dem Konzil wichtige Implikationen. Es wurde das ganze System der gegenseitigen Bezüge zwischen Christen und Juden aufgebaut. Zu ihm gehören repräsentative Strukturen, die dem Dialog Anstoß geben und die Ebende der gegenseitigen Beziehungen neu bestimmen.

Der Standpunkt des jüdischen Gesprächspartners ist komplex und bietet für die meisten Christen manche Schwierigkeiten. Die gröste Schwierigkeit beruht darauf, daß es Judaismus viele Orientierungslinien gibt, die sich nicht immer zu einem einheitlichen Ganzen zusammenfügen lassen. Das International Jewish Committee on Interreligious Consultations bringtzwar allgemeine Stimmungen im Dialog zwischen Kirche und jüdischer Gemeinschaft zum Ausdruck, jedoch es behandelt nicht ausfürlich genug komplizierte Stellungen und Haltungen der Juden gegen alle Aktivitäten der Kirche. Diese Stellungen sind vertreten sowohl von den Anhängern und für die Annäherung Begeisterten als auch von Skeptikern oder sogar Gegnern des Dialogs. Die negativen Haltungen gehen teils auf die historischen, teils auf die religiösen Ressentimente zurück und scheinen manchmal Vorherrschaft über die der Protagonisten des Dialogs zu gewinnen. Anhang der Erfahrungen der Zeit nach dem Konzil kann man auf einige Punkte hinweisen, die in den Äußerungen der jüdischen Seite konsequent zum Ausdruck kommen. Das sind: Verhältnis der Kirche und Synagoge, Person Christi, Bedeutung des Judaismus heute und im Zusammenhang damit die Rolle des Staates Israel, die nach Ansicht der Juden einen religiösen Wert hat. Nach diesen Themengruppen werden von den jüdischen Kommentatoren die einzelnen Urkunden der Kirche, die die Dialogsfrage erörtern, untersucht. Unter deren Gesichtspunkt verfolgen sie auch die Stellungnahme Johann Pauls II. Und sein Engagement in die Judenfrage.

Unter allen die Verständigungsfrage bejahenden Stellungnahmen nehmen die Äußerungen der jüdischen Konvertiten einen besonderen Platz ein. Sie sind eine wertvolle Stütze, die Natur der Juden richtig zu verstehen.

Obwohl der Annäherungsprozeß zwischen Juden und Christen noch ein langer Weg vor sich hat, kann man wohl feststellen, daß auf der jüdischen Seite ein Klima des Vertrauens, übringens das Bewußtsein ensteht, daß die Judenfrage in der katholischen Kirche Anklang finden wird. Letzten Endes wird es doch von Gott des Israels und Jesu abhängen, ob die Christen und Juden, jeder auf seine Art, aber gemeinsam, die Vision der Zukunft, deren Ausdruck Nostra aetate ist, verwirklichen. 